\title{
Composite with Recyclable Loads for the Manufacture of Blocks to Build Popular Houses
}

\author{
Luiz Guilherme Meira de Souza, Flavio Anselmo Silva de Lima, Luiz Guilherme Vieira Meira de Souza, \\ Natanaeyfle Randemberg Gomes dos Santos and Jaílton Weber Gomes \\ Department of Mechanical Engineering, Universidade Federal do Rio Grande do Norte, Natal 59078-970, Brazil
}

Received: April 11, 2014 / Accepted: April 29, 2014 / Published: September 25, 2014.

\begin{abstract}
The science space in a state school in Natal city was built using a composite consisting of gypsum, EPS (expanded polystyrene), shredded tire, cement and water. Mechanical and thermal resistances were evaluated. Inside the blocks, three types of fillings (EPS plates, aluminum cans and $500 \mathrm{~mL}$ bottles of mineral water) were placed in order to obtain a walls with higher thermal resistance, but also to give it an ecologically correct order, considering that both the tire and the EPS occupy a large space in landfills and require years to be degraded when released into the environment. Compression tests were conducted according to the rules. The experiments demonstrated that the temperature difference between the internal and external surfaces on the walls reached levels above $12.0{ }^{\circ} \mathrm{C}$. It was also demonstrated that the proposed composite has adequate mechanical strength to be used for sealing walls. The proposed use of the composite can contribute to reduce the significant housing deficit of Brazil, producing popular houses at low cost and with little time to work.
\end{abstract}

Key words: Solar composite, low cost, thermal resistance, mechanical resistance, materials reuse, housing.

\section{Introduction}

In Brazil, there are a large number of families living in inadequate conditions as to food, education, sanitation and habitat. Aiming to supply these deficiencies, many public programs have been created with the aim to build and provide social housing with the minimum desirable for low-income families [1].

For this purpose, a new type of block was developed using composite material in order to reduce the cost of building a house, and contribute to existing efforts to reduce the housing deficit [1-5].

This block contains in its composition shredded tire, gypsum, EPS (expanded polystyrene), cement and water. The fillings of the blocks can be EPS plates, aluminum cans and bottles of mineral water. In this paper, the authors present the results for tests with such

Corresponding author: Flavio Anselmo Silva de Lima, E-mail: flavio_bk@yahoo.com.br. fillings.

The composite has good homogeneity, the blocks produced are easy to manufacture and assembly and present low thermal conductivity and can be used for different manufacturing techniques.

The block studied has in its formulation cement, gypsum, styrofoam, shredded tires, and filling plates of recycled EPS. These blocks have $26 \mathrm{~mm}$ width, $80 \mathrm{~mm}$ length and $10 \mathrm{~mm}$ thickness. This enables greater speed in the construction of housing in relation to conventional bricks (eight holes ceramic blocks) due to its greater area.

This block has the following main features: low cost, good compressive strength, low thermal conductivity, good esthetics, low weight, versatility and easy manufacturing and assembly processes.

Another major advantage of the produced composite is its rapid complete drying process allowing considerable flexibility of the construction process. The advantage of good surface finishing of the 
produced block should also be noted

The paper is organized as follows: Section 2 presents the materials and processes used to manufacture construction blocks and space science; Section 3 presents results and discussions; and Section 4 gives conclusions and presents future work.

\section{Materials and Methods}

The composite used in the blocks presented the following proportions by volume: 1.0 gypsum part + 1.0 crushed styrofoam part +1.0 cement part +1.0 part craps tire +0.4 part of the total volume of water.

Fillings were used in blocks. EPS recycled plates, cans of beers and soft drinks, and pets bottles of mineral water $500 \mathrm{~mL}$. The dimensions of the block were $L=80 \mathrm{~cm}, W=26 \mathrm{~cm}$ and $H=10 \mathrm{~cm}$, with an area of $0.21 \mathrm{~m}^{2}$ and volume of $0.021 \mathrm{~m}^{3}$ [1-3].

To manufacture the block with the fillings, selected procedures were adopted: the mold assembly; application of the release agent in the mold; dosage of the components for the manufacture of the blocks; dry mixing and homogenization of the components; homogenizing the mixture with water; filling the mold with the composite; placing of the filling, removing the mold components; monitoring the cure.

For the filling, styrofoam plates from whole packs of split type air conditioners were used; bottles of soft drinks were 12 in number and cans of beer and soft drinks 15 in number. Fig. 1 shows the steps of manufacturing the proposed block.

To test the composite's thermal resistance, a science space was built in a state school located in Natal-RN (Rio Grande do Norte). About 75 blocks were used for that building. Fig. 2 shows some views of the walls of the built science space that has an area of $27.0 \mathrm{~m}^{2}(6.28$ $\mathrm{m} \times 4.30 \mathrm{~m}$ ) and walls with the height of $2.44 \mathrm{~m}$ and 0.10 to $0.13 \mathrm{~m}$ thickness.

For the characterization of the composite, tests were carried out for several formulations to determine the thermal conductivity, density, strength, percent water absorption and heat resistance.

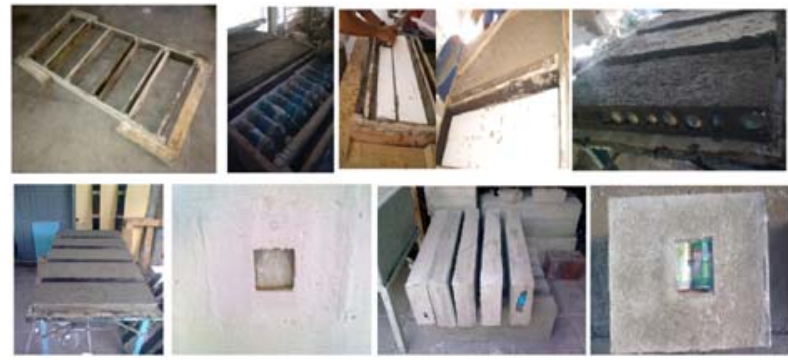

Fig. 1 Manufacturing steps of blocks with three fillings.


Fig. 2 Views of the walls of the built space.

The thermal performance analysis of residential units was made for daytime. The temperatures of the internal walls, external sunny side (south) of the internal environment were collected directly at every $15 \mathrm{~min}$ in at least eight hours, 8:00 a.m. to 04:00 p.m. It was also collected for the same period the thermal sensation of the external environment and the global solar radiation.

\section{Results and Discussions}

The following presents the results of characterization of the composite with respect to physical, thermal and mechanical properties.

\subsection{Determination of Thermal Conductivity}

Table 1 shows average values of the thermal conductivity.

The composite showed low thermal conductivity, but higher than other tested compositions. The introduction of the tire scrapes caused an increase of 
Table 1 Average thermal conductivity.

\begin{tabular}{ll}
\hline Composition type & $K\left(\mathrm{~W} / \mathrm{m} \cdot{ }^{\circ} \mathrm{C}\right)$ \\
\hline CGE & 0.20 \\
CGT & 0.37 \\
CGET & 0.26 \\
\hline
\end{tabular}

C: cement, G: gypsum, E: EPS and T: tire scrapes.

$30 \%$ in relation the crushed EPS. The thermal conductivity was closest to the gypsum's than to the polystyrene's and the tire scrapes.

\subsection{Determination the Specific Mass of the Composite}

Table 2 presents the mass of each of the composite formulation and their specific mass.

The composite is much lighter than common brickwork (density of $1,600 \mathrm{~kg} / \mathrm{m}^{3}$ ), which is a very positive factor during the laying of the blocks.

\subsection{Test of Compression Resistance}

Table 3 shows the values of compressive strength obtained for all tested configurations after 7, 14 and 28 days of curing.

The compression strength was $35.0 \%$ above the one shown by the standard, but it is clear that the mixing EPS-Tire does not produce a high mechanical strength. The other studied composites compositions showed higher levels in this parameter.

\subsection{Thermal Resistance Test}

Tables 4-6 show the values of the three days of diagnostic tests for thermal comfort for the three types of filling.

The maximum temperature difference achieved between the external and internal walls occurred in the third test day, corresponding to $12.4^{\circ} \mathrm{C}$ at $01: 30$ p.m. It should be noted that this day had a higher rate of incident global radiation.

The average temperature difference between the external and internal wall was significant, reaching an average value of about $4.0{ }^{\circ} \mathrm{C}$.

In relation to other blocks manufactured in the same geometry, the results achieved were higher, especially
Table 2 Specific masses of the tested formulations.

\begin{tabular}{lc}
\hline Composition type & Specific mass $\left(\mathrm{kg} / \mathrm{m}^{3}\right)$ \\
\hline CGE & 882.1 \\
CGT & $1,271.9$ \\
CGET & 914.2 \\
\hline
\end{tabular}

Table 3 Compressive strength.

\begin{tabular}{llll}
\hline \multicolumn{4}{c}{ Compression strength (MPa) } \\
\hline Composition & 7 days & 14 days & 28 days \\
\hline CGT & 3.10 & 4.18 & 4.31 \\
CGET & 1.5 & 1.84 & 2.02 \\
CGEC & 2.70 & 2.80 & 2.90 \\
\hline C: clay. & & &
\end{tabular}

Table 4 Average of thermal comfort tests-EPS filling.

\begin{tabular}{lllll}
\hline Days & $\begin{array}{l}T_{\text {wall external }} \\
\left(\mathrm{C}^{\circ}\right)\end{array}$ & $\begin{array}{l}T_{\text {wall internal }} \\
\left(\mathrm{C}^{\circ}\right)\end{array}$ & $\Delta T\left(\mathrm{C}^{\circ}\right)$ & $S T\left(\mathrm{C}^{\circ}\right)$ \\
\hline 1 & 37.2 & 32.6 & 4.6 & 35.5 \\
2 & 37.7 & 33.2 & 4.5 & 36.0 \\
3 & 39.1 & 33.4 & 5.7 & 36.0 \\
\hline
\end{tabular}

ST: thermal sensation.

for the period between 01:00 p.m. and 02:00 pm, with temperature differences of around $10{ }^{\circ} \mathrm{C}$. These findings are relevant for obtaining a good thermal comfort in the interior of dwellings.

Solar conditions of test days were very good, recording solar radiation peaks around $1,000 \mathrm{~W} / \mathrm{m}^{2}$, and average above $730 \mathrm{~W} / \mathrm{m}^{2}$, and average relative humidity around $60 \%$.

The maximum temperature difference achieved between the external and internal walls occurred in the third test day, corresponding to $11.5^{\circ} \mathrm{C}$ at 01:30 p.m. The average temperature difference between the external and internal wall reached average of $4.2^{\circ} \mathrm{C}$.

In relation to other blocks manufactured in the same geometry, the results achieved were higher, especially for the period between 01:00 p.m. and 02:00 p.m., with temperature differences of around $9{ }^{\circ} \mathrm{C}$. These findings are relevant for obtaining a good thermal comfort in the interior of dwellings.

The maximum temperature difference achieved between the external and internal walls occurred in the third test day, corresponding to $11.7^{\circ} \mathrm{C}$ at 01:30 p.m. The average temperature difference between the 
Table 5 Average of thermal comfort tests-cans filling.

\begin{tabular}{|c|c|c|c|c|}
\hline Days & $\begin{array}{l}T_{\text {wall external }} \\
\left({ }^{\circ} \mathrm{C}\right)\end{array}$ & $\begin{array}{l}T_{\text {wall internal }} \\
\left({ }^{\circ} \mathrm{C}\right)\end{array}$ & $\Delta T\left({ }^{\circ} \mathrm{C}\right)$ & $S T\left({ }^{\circ} \mathrm{C}\right)$ \\
\hline 1 & 36.8 & 32.6 & 4.2 & 35.5 \\
\hline 2 & 36.8 & 33.1 & 3.7 & 36.0 \\
\hline 3 & 38.0 & 33.4 & 4.7 & 36.0 \\
\hline
\end{tabular}

Table 6 Average of testing for thermal comfort-filling bottles.

\begin{tabular}{|c|c|c|c|c|}
\hline Days & $\begin{array}{l}\mathrm{T}_{\text {wall external }} \\
\left({ }^{\circ} \mathrm{C}\right)\end{array}$ & $\begin{array}{l}T_{\text {wall internal }} \\
\left({ }^{\circ} \mathrm{C}\right)\end{array}$ & $\Delta T\left({ }^{\circ} \mathrm{C}\right)$ & $S T\left({ }^{\circ} \mathrm{C}\right)$ \\
\hline 1 & 37.0 & 32.4 & 4.6 & 35.5 \\
\hline 2 & 37.1 & 32.9 & 4.2 & 36.0 \\
\hline 3 & 38.4 & 33.2 & 5.3 & 36.0 \\
\hline
\end{tabular}

Table 7 Parameters average for the diagnosis of thermal comfort of the blocks.

\begin{tabular}{llll}
\hline Filling type & $\Delta T_{\max }\left({ }^{\circ} \mathrm{C}\right)$ & $\Delta T_{\text {ave }}\left({ }^{\circ} \mathrm{C}\right)$ & $I_{g}\left(\mathrm{~W} / \mathrm{m}^{2}\right)$ \\
\hline EPS & 12.4 & 5.0 & 720.0 \\
Cans & 11.5 & 4.2 & 732.6 \\
Bottles & 11.7 & 4.7 & 752.5 \\
\hline
\end{tabular}

external and internal wall was significant, reaching an average value of about $4.7^{\circ} \mathrm{C}$.

In relation to other blocks manufactured in the same geometry, the results achieved were higher, especially for the period between 01:00 p.m. and 02:00 p.m., with temperature differences of around $9.5{ }^{\circ} \mathrm{C}$. These findings are relevant for obtaining a good thermal comfort in the interior of dwellings. Table 7 shows the average temperature measured for the three types of fillings used.

The highest thermal insulation was provided by the EPS filling, although other fillings also proved themselves to be efficient in providing adequate thermal comfort conditions inside houses.

All fillings are harmful to the environment elements if left exposed, so their use constitutes an important factor for the preservation of the nature.

Regarding the manufacturing process of the blocks there is an additional complication to the use of all tested fillings. The filling that was easier to manufacture was to EPS plate.

A thesis is in development in order to test these fillings along with different proportions between the constituents of the composite. A house will be built and

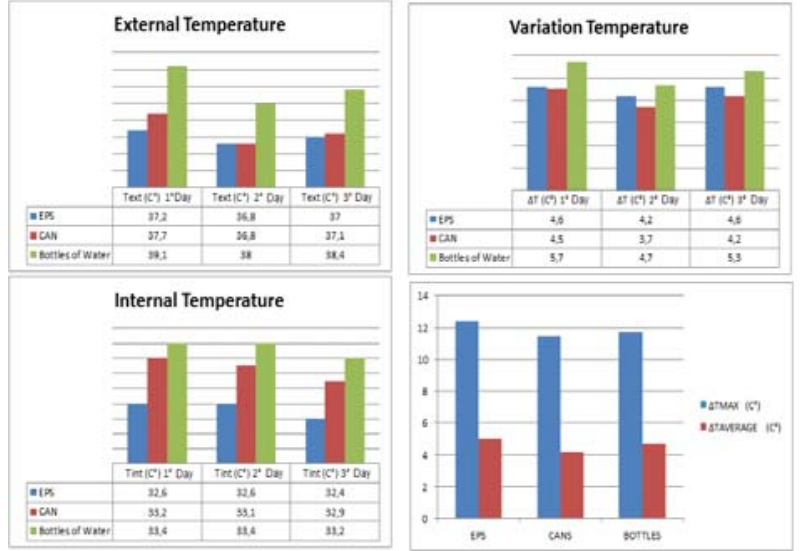

Fig. 2 Behavioral parameters analyzed during test.

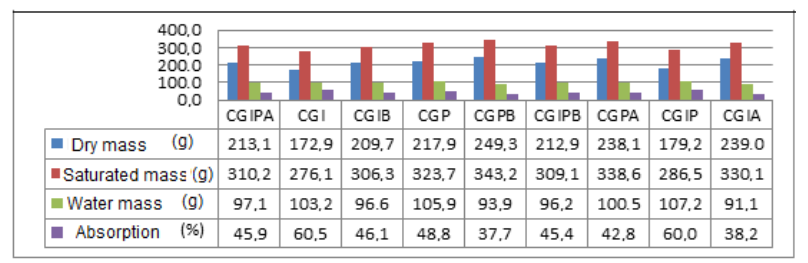

Fig. 3 Parameters behavior in the water absorption.

the thermal comfort generated by these blocks will be evaluated. The tests performed indicate a viability of generating significant thermal comfort.

Fig. 3 shows the behavior of the analyzed parameters during the tests.

\subsection{Water Absorption}

Fig. 4 shows the behavior of the parameters during the tests to determine the composite's percentage of water absorption.

All formulations can be used as building elements with respect to water absorption. The most effective formulation was CGEC with a percentage lower than $40.0 \%$.

The constitutions without sand or clay have high water absorption, about $60 \%$, but this absorption does not compromise its use for the manufacture of plates. As they are sealed in paint, there is a significant reduction of this problem.

\section{Conclusions}

(1) The composite studied is feasible to be used as construction material;

(2) Due to the good heat resistance of the composite 
blocks, a good thermal comfort is expected in the interior of a house built with these blocks;

(3) The manufacturing process is simple and its technology can be transferred to needy communities for people of any cultural levels;

(4) A large block enabled a faster construction of the science space since its area is greater if compared to a red ceramic brick;

(5) The reuse of harmful to the environment materials, such as EPS and tire constitutes an ecological action of great importance to the environmental preservation;

(6) The residence manufacturing cost can be reduced since it significantly reduces the cost of labor.

\section{References}

[1] Lima, F. A. S. 2012. "Estudo de um compósito de matriz cerâmica com cargas de EPS e raspa de pneu para construção de casas populares." Master dissertation, Federal University of Rio Grande do Norte.

[2] Gomes, I. R. B. 2010. "Viabilidade de utilização de um compósito a partir de resíduos para a construção de casas populares a baixo custo." Master dissertation, UFRN.

[3] Silva, A. R. 2010. "estudo térmico e de materiais de um bloco para construção de casas populares, confeccionado a partir de um composto a base de gesso, eps e raspa de pneu." Master dissertation, UFRN.

[4] Leite, J. M. C. C. 2011. "Composite for the Manufacture of Blocks for Construction of Houses: Thermal and Study Materials." Master dissertation, UFRN.

[5] Macedo, M. C. 2011. "Composite Materials Based on Plaster and EPS for Construction of Popular Housing." HOLOS.

[6] Silva, C. R. R. 2010. "Viabilidade de utilização de um compósito a partir da queima dos resíduos de dendê para a construção de casas." Master dissertation, UFRN.

[7] Rodrigues, S. M. 2012. "Viabilidade da utilização de material compósito na construção civil." Master dissertation, UFRN.

[8] NBR 15270-1/2005. Ceramic sealing masonry blocks.

[9] NBR 6.461, 1983. Ceramic block masonry-Verification of resistance to compression: test method.

[10] NBR 15220-3/2005, Thermal performance of buildings (part 3: Brazilian and Constructive Guidelines they Zoning for Single-family Dwellings of social interest). 